УДК: $37.013 .73+37.022$

\title{
Олег ГІРНИЙ
}

\section{АНДЖЕЙ ҐЖЕҐОРЧИК ЯК ФІЛОСОФ ОСВІТИ}

\author{
Філософам, яким не йдеться про власну ори- \\ гінальність, залишилося ще одне важливе за- \\ вдання - добре впорядкувати банальні речі.
}

Анджей Гжегорчик

У статті представлено науковий портрет видатного польського вченого, останнього представника знаменитої Львівсько-варшавської логіко-філософської школи, великого друга України, професора Анджея Гжегорчика, другі роковини смерті якого минули в цьому році. Окрім своєї головної пасії - математичної логіки, в якій йому належать визнані в усьому світі результати, Анджей Гжеггорчик займався етикою та філософією, зокрема тим ї̈ видом, який сам називав «раціоналізмом, відкри-

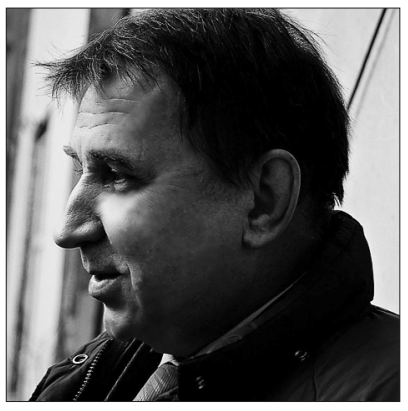
тим до цінностей».

Коротко описано також його доробок у тій сфері, яку часто називають «філософією освіти», хоча, у багатьох випадках слід говорити радше про «філософію в освіті». Ця ділянка незаслужено вважається другорядною в його творчості, хоча насправді має першорядне значення для розвитку теоретичних основ педагогіки. На особливу увагу в останніх заслуговує, зокрема його наукова програма антропологічного опису так званої «людської кондиції», а також розроблена ним, на основі цього опису так звана «Універсальна навчальна (икільна) програма».

Ключові слова: логіка, раціоналізм, цінності, філософія освіти, теоретичні основи педагогіки, людська кондиція, антропологічний опис, універсальна освітня програма.

У цьому році минула друга річниця смерті видатного польського вченого та мислителя, останнього представника знаменитої Львівсько-варшавської школи, дійсного члена Польської академії наук, Професора Анджея Гжегорчика. Його постаті та науковому доробку було, зокрема, присвячено секцію на міжнародній конференції «Філософія діалогу й порозуміння в побудові європейської й світової спільноти», організованої Міністерством освіти і науки України, яка відбулася у Львівському 
національному університеті імені Івана Франка за участю, серед інших, численної групи учасників із Польщі.

Писати про професора Анджея Гжегорчика як про філософа освіти є і важко, і легко водночас. Легкість писання про Анджея Гжегорчика загалом, випливає з особистого знайомства з ним. Я не лише мав щастя познайомитися з Професором А. Гжегорчиком особисто, але й зав'язати з ним багаторічну співпрацю. У дуже делікатний спосіб він тоді заопікувався моєю філософською освітою, також у вигляді наукового стажування під його керівництвом. Разом зі своєю дружиною, професором Ренатою Гжегорчик, гостив мене у своєму затишному помешканні на вулиці Фільтровій у Варшаві, оточуючи батьківською та материнською сердечністю, завжди цікавлячись справами в Україні та у Львові. Він був гарячим прихильником польсько-українського поєднання та співпраці, про що писав у не одній своїй статті. Частину з них мені вдалося перекласти та опублікувати українською у львівських часописах. Кожна зустріч з Професором Гжегорчиком упродовж усього часу нашого знайомства підтверджувала влучний вислів про нього: „3 цією Людиною неможливо програти”.

Легкість писання про Професора Анджея Гжегорчика як ученого, що працював у галузі педагогіки, випливає насамперед із його робіт, публікованих у педагогічних журналах і збірниках, в яких він викладав свої погляди на розвиток освіти, обумовлені його власними дослідженнями в галузі філософії. Що ж стосується вкладу Анджея Гжегорчика у педагогіку, він випливає із загального відношення педагогіки та філософії, i\ або - педагогіки та науки.

По-перше, філософія надає педагогіці засадничі усталення стосовно, зокрема, людини та ії пізнання, і тим самим стає теоретичним тилом педагогіки - як у їі дидактичній, так і у виховній частині. 3 цього погляду всі роботи Професора Гжегорчика з етики (наприклад $[1,6,12,13,17])$, психології ([25]), антропології ([15, 23, 24, 26]), та педагогіки ([4, 19, 21, 22]) - належать також до галузей, які у формальній українській класифікації називаються „теорія та методика виховання”, „історія і теорія педагогіки” та „філософія освіти”.

По-друге, як він сам писав - „філософам залишилося одне важливе завдання - добре упорядкувати банальні речі". I саме це упорядкування, з педагогічного погляду, об’єднує філософію з наукою. У цьому місці варто згадати, що слово „наука” в українському (як і в польському) слівництві має подвійне значення. 3 одного боку, воно означає діяльність, що полягає у пошуку та відкриванні нових, досі невідомих істин про світ і людину. 3 другого - діяльність, що полягає в упорядкуванні вже існуючих знань у якомога більш зв'язну систему відомостей - з метою їх пере- 
дання наступним поколінням. Тобто є педагогікою sensu largo. Віддзеркаленням цієї двоїстості є поширена в усьому світі європейська традиція присвоєння найвищих наукових ступенів і звань. Вищі наукові ступені: «доктор філософіï» (Phylosophy Doktor) і «доктор наук» (Doktor Habilitate) - присвоюються за наукові досягнення у першому значенні науки, тобто - в галузі відкривання нових знань. А вищі наукові звання: «доцент» (Docent) і «професор» (Profesor) - присвоюються за наукові досягнення в другому значенні науки, тобто - в галузі порядкування (систематизаціі) та передавання молодим поколінням існуючих знань - зазвичай, у вигляді статей і книжок. Останнє часто є тісно пов'язане з безпосередньою педагогічною діяльністю - особистим переказуванням знань у вигляді лекцій у вищих навчальних закладах. 3 цього погляду праці Професора Гжегорчика, в яких він зв'язно представляє існуюче знання в царині логіки, яку ще й викладав особисто студентам, а саме: Нарис математичної логіки [11], Популярна логіка [7, 9, 29], Нарис теоретичної арифметики [10] - це педагогічні праці найвищого рівня.

Ця, дуже трудомістка, робота, що часто поглинає більшу частину часу науковця - у тій же традиції європейської науки, вважається моральним (а зараз також і формальним) обов'язком учених, зокрема професорів, тобто чимось рутинним, а відтак, на жаль, особливої реакції не викликає - у тому числі й у самих авторів. Закінчивши написання та публікацію книжки з культивованої ним науки, учений скидає з себе тягар дидактичного обов’язку і рушає далі у своїх наукових дослідженнях. I так - до наступного підсумовування своїх досягнень у наступній книжці. 3 цього погляду кожен професор у своїй царині є водночас (ніби автоматично) дидактом, тобто педагогом.

Натомість, рідко хто із науковців опускається до обмірковування навчання не дорослих студентів, а учнів середніх шкіл, яке (навчання) вимагає не тільки (а може і не стільки) зв'язного і повного викладу „усієї” науки даного предмета, скільки якомога доступнішого та зрозумілого для них впровадження у цей предмет - такого, щоб не відразити, а зацікавити, привабити. I тут ми вже маємо педагогіку в тому їі розумінні, в якому поточно говориться про педагогіку та педагогів. Кажуть, що для цього треба бути справжнім «філософом свого предмета».

Отож Професор Гжегорчик належить до нечисленного грона тих професорів, які похиляються до шкільної науки, думаючи про освіту дітей як про основу загального рівня освіти в суспільстві. Це - чудовий приклад живої традиції знаменитої Львівсько-варшавської школи, членом і працьовитим продовжувачем якої він без сумніву був.

3 думкою про учнів середніх шкіл він написав низку вже згаданих книжок, що популяризують його улюблену наукову дисципліну - мате- 
матичну логіку. Книги ці не лише видавалися по кілька разів, але також перекладалися іноземними мовами. Так, наприклад Популярна логіка, що видавалася тричі [9], була перекладена також російською та чеською, а через п'ятдесят років, з підзаголовком Доступний нарис логіки пропозицій - була видана учетверте [29], Нарис математичної логіки мав п’ять видань [11], Нарис теоретичної арифметики - два [10]. У цьому місці доречно нагадати, що популяризаторство становить особливий вид наукового письменництва, взятися за який здатні дуже нечисленні науковці, що обумовлює високу дидактичну (педагогічну) цінність цього роду наукової літератури.

3 думкою про учнів середніх шкіл він написав також дві книжки 3 філософської пропедевтики. Перша - Мала пропедевтика наукової фiлософії- з'явилась у 1989 році [14], друга - Життя як виклик. Вступ до раціоналістичної філософії - у 1993 і 1997 [20]. Цю останню - з якої почалася також моя співпраця з Професором - на пострадянському ринку вважаю найкращою книжкою з філософської пропедевтики. У ній однорідно i, що найважливіше - доступно, він виклав основний тезаурус всіх сучасних філософських дисциплін: логіки й онтології, антропології, праксеології, епістемології, аксіології, а також споріднених із ними психології та соціології.

Я мав щастя перекласти цю книжку ${ }^{1}$, вчитися по ній i, водночас - peалізувати один із найвдаліших дидактичних проектів, а саме - апробувати складену на її основі програму Філософської пропедевтики у старших класах однієї з львівських шкіл². Можу сказати, що український експеримент з пропедевтикою філософії за книжкою Професора Гжегорчика виявився надзвичайно успішним. У висліді однорічного навчання пропедевтики філософії учнів 10-х і 11-х класів було отримано низку важливих результатів.

Насамперед, шкільна філософія, обумовлена сучасним станом філософії, що складається з низки філософських наук - не є пропедевтикою «якоїсь» філософії як такої, а пропедевтикою філософських наук. Подібно, як шкільна фізика є пропедевтикою фізичних наук, географія - географічних, біологія - біологічних і т.д. Підручник А. Гжегорчика є збір-

${ }^{1}$ Див. [2]. Цей переклад, у свою чергу, послужив мені рекомендацією у Львівському видавництві „Свічадо”, як члена групи перекладачів, залучених до перекладу відомого польського шедевру Вл. Татаркевича „Історія філософії” - для потреб студентів Львівської богословської академії (тепер - Львівський католицький університет). (O.H.)

${ }^{2}$ Паралельно підручник А. Гжегорчика апробувався в іншій львівській школі Ліцеї імені Климентія Шептицького, де уроки з пропедевтики філософії вів Ігор Карівець - тодішній аспірант філософського факультету Львівського національного університету імені Івана Франка. (О.Н.) 
ником текстів, який чи не вперше презентує учням на наших теренах сучасну philosophy as science - наукову філософію. І укладена за нею програма занять справдилась як програма повноцінного шкільного предмета, що віддзеркалює певну царину академічних наук (власне філософських), які до цього часу були не-, або слабо представлені в шкільних програмах. 3 цього погляду іiі можна порівняти лише з рекомендованою Польським MEN у 1982 році Програмою філософської пропедевтики для ліцеїв авторства проф. Я. Ядацького (яка, на жаль, так і не дочекалася підручника), а також - з відомим німецьким університетським підручником «Філософія. Єдиний базовий курс» Г. Шнадельбаха і I. Мартенса, виданим у Польщі під назвою „Філософія. Основні питання” [34], який представляє філософію як проблемно упорядкований збірник наукових статей.

По-друге, ми з’ясували ступінь зацікавленості учнів різними розділами програми. Рейтинг зменшення зацікавленості виглядає так: 1) Міжлюдські стосунки як основа суспільного життя (Вступ до соціальної філософії); 2) Філософія діяльності (Вступ до праксеології); 3) Звідки беруться цінності (Bcmуn до етики); 4) Людина та дійсність (Встуn до антропології); 5) Мовне реконструювання світу (Вступ до гносеології); 6) Загальна будова світу (Вступ до онтології); 7) Європейська філософія (Bcmyn до історії філософії); 8) Початок філософії (Предмет філософії) ${ }^{1}$

По-третє, ми виявили можливості та переваги впровадження філософії в школу як окремого предмета. Отож, філософія як окремий предмет - це найкраще вирішення саме для старшокласників, причому обов’язково у вигляді philosophy as science. А от філософія в основній і навіть початковій школі - найкраще підходить у вигляді philosophy as literature.

По-четверте, філософія - і як інтелектуальна сфера, і як академічний предмет - не має сьогодні монополії на розвиток мислення чи особистість учня. Вона залишається підбудовою всіх умінь - і як дидактична наука, і як мистецтво навчання. Тому неможливо ставити в школі перед одним предметом цілі, які стоять перед усіма предметами. Звідси - шкільній філософії у рамках окремого предмета слід підпорядковувати добре відомі дидактичні завдання. А саме: формування в учнів так званих „предметних компетентностей”, тобто - надання визначених знань, умінь і практичних навиків.

\footnotetext{
1 Зміст програми, дидактичні розробки та хід занять були докладно представлені у доповіді на конференції Польського філософського товариства „Філософія в школі” (Філософія як основа інтеграції навчання та виховання. Кєльце, 21-22 вересня 2001). Див., зокрема. [31]. (О.Н.)
} 
Підсумовуючи, можна сказати, що застосування книжки Професора Гжегорчика „Життя як виклик. Вступ до раціоналістичної філософії” як підручника пропедевтики філософії, дозволили зрозуміти певні тенденції стосовно їі місця і ролі в школі. Отож, окрім вдалого синтетичного представлення системи понять сучасних філософських наук, до них можна віднести залежність навчання філософської пропедевтики в школі від:

- іiі статусу у навчальних планах, обумовленого кон'юнктурою на професійному ринку, а також вимог вищих навчальних закладів, наприклад - від наявності вступних чи випускних іспитів з цього предмета;

- ступеня зацікавленості філософською освітою серед учителів, зокрема - нефілософських шкільних предметів;

- способу впровадження філософських змістів у шкільні програми: як окремого предмета чи як між-предметного зв'язку;

- від врахування (чи неврахування) філософії як методики розвивального навчання.

Остання опція, яка у цьому випадку становить над-мету, безпосередньо випливає з проблеми, яку поставив Професор Гжегорчик: якими $\epsilon$ філософські складники думки, що виступають в основах усіх наук і в основах усіх світоглядних переконань, які сформувалися в період виникнення людських мов і в них помітні, та які потім з поточної мови переходять у наукові та професійно філософські формулювання? [28]

$$
* * *
$$

Натомість, якщо говорити про Професора А. Гжегорчика як про філософа освіти, то писати про це важко. Тому, що його головною науковою пасією була логіка і він відомий у світі, передусім, як видатний спеціаліст з математичної та символічної логіки, автор багатьох праць 3 цієї галузі науки, перекладених багатьма іноземними мовами. А от його доробок в інших галузях суспільних і - ширше - гуманітарних наук досі залишається недооціненим і ніби на узбіччі наукової думки, незважаючи на те, що психологічна, освітня. антропологічна, етична та філософська проблематика займали левову частку його творчості останніх десятиліть його діяльності.

Крім того, філософія освіти як окрема філософська наука викликає неоднозначне ставлення з боку різних професійних наукових середовищ. Після виходу у 2001 році книги російського філософа Фелікса Михайлова «Філософія освіти: ііі реальність і перспективи» [8] поняття філософії освіти на пострадянському просторі, отримало подвійне трактування - «філософія освіти» та «(мета)теорія освіти». Сам Ф. Михайлов вважав, що фі- 
лософія освіти - річ принципово неможлива. По-перше, за своєю суттю філософія принципово не може бути частковою (особливою), а по-друге - численні теорії освіти, які емпіристськи визначають предмет освітньої діяльності (що, з одного боку є просто помилкою, а з другого - не є предметом власне філософії), насправді не мають своєї фундаментальної основи. Відтак, ті змістові конструкції, що їх вибудовують теоретики освіти, з метою «знайти шлях до розуміння сенсу вихідних понять про предмет цієї науки, і які в дослідженнях цього предмета мисленно моделюють Його об'єктивні властивості» - це насправді звичайні теоретичні та метатеоретичні пошуки в межах конкретної (часткової) науки.

Конкретні (часткові) науки не відбрунькувались від філософії, а виникли як “початки” власне теоретичної діяльності в різних формах іiі предметності. Філософія ж від початку виникла як "рефлексуюча на себе теорія проблем буття в його усвідомленості” - теорія вічних проблем пізнання, що представляє та перетворює світ. Теоретики часткових наук вступають на шлях філософії тільки тоді, коли звертаються до проблем теоретичного обгрунтування самої здатності буття бути осмисленим. Предметом філософії є не та чи інша наука, не їх сукупність і навіть не найзагальніші висновки з усіх часткових знань, а сама можливість розуму породжувати «осмислено чуттєвий образ» вічно всезагального та завжди «афективного знання» про вічне, джерело якого від початку було не в науці.

Філософія, що має справу з «усезагальним» - тим, що перебуває в усіх формах відношенням свідомості до буття. Саме ж це відношення (опосередковане суб'єктивно мотивованими зверненнями свідомих себе людей до суб’єктивності собі подібних) також існує лише у всезагальних формах засобів звернення (канонах, правилах, традиціях, ритуалах і т.п.). У тих сферах пізнавально-перетворювальної діяльності, в яких фундаментальна основа її предметності теоретично не експлікована i, тим самим, сама не стала предметом творчого перетворення й розвитку, філософія здатна виконати лише допоміжні функції, які великий Сократ вдало охрестив маєвтикою - мистецтвом прийняття пологів. Відтак, завданням філософії освіти є первинне обгрунтування предметності і предмета сфери педагогіки.

У iii компетенцію входить відрізнення умов, за яких може здійснитися постулювання визначень предметності та предмета освітньої (педагогічної) теорії - від іiі постулатів як таких. Теоретичне визначення умов постулювання - це постійно поглиблювана історія способів, форм і засобів відтворення людьми свого громадського життя, постійно відтворювана в нашій свідомості, перш за все - побутовою культурою мови, праці, мислення, що продовжує себе в усіх формах, всіма “архетипами” свідомості та неусвідомленою сферою психіки кожного з нас. Дієвість усіх цих за- 
собів не в їхній подобі до природних і суспільних процесів (навіть якщо вони й винайдені способом наслідування їх), а у їхній суб'єктивності. Цю суб’єктивність і слід постулювати навіть тоді, коли мова заходить про необхідність фундаментальної теорії освітньої діяльності.

Ця теорія від початку є частиною певного органічного цілого, а саме - загального людинознавства, згідно з яким: Породжуючим $i$ зберігаючим людину відношенням є ї відношення до суб'єктивності інших людей, яке шукає спів-чуття, с (пів)-відомості та з(пів)-годи у спів-діянні з ними, що формує мотивацію їхньої та ї̈ поведінки, здатне забезпечити розширене відтворення (створення) засобів для життя та його головних умов: самоорганізовувану спільноту людей, ï̈ креативну й когнітивну духовну і духовно-практичну продуктивність. [8]

Немає жодної здібності душі людини, яка б не народжувалась, не зберігалась і не розвивалася б у якості ії внутрішнього суб'єктивного стану інакше як у просторі зустрічі та взаємної (роз)мови вікових когорт і поколінь. Відтак, саме цим простором і слід займатися педагогам.

3 положень загального людинознавства випливають головні постулати фундаментальної теорії освітньої діяльності.

1: Предметним полем (предметністю) педагогічної науки є реальноідеальний простір освітнього спілкування вікових когорт, поколінь і різних професійних об'єднань - навіть у тому випадку, коли це освітнє спілкування співпадає з просторами соціальних форм будь-якого іншого їх спілкування.

2: Предметом теорії освітньої діяльності є штучні засоби та способи перетворюючого розуміння різних форм освітнього простору: постулати, логічні висновки з них, - які створюють поняття часткових форм освітньої діяльності, поняття про логіку ії інтелектуально-естетичного сприйняття суб'єктами педагогічної теорії та практик і інші, виводимі з них, що не виходять за межі освітньої предметності (див. перший постулат).

3: Мета фундаментальної теорії освітньої діяльності - апріорним логічним слідуванням із перших постулатів забезпечити розуміння процесів цієї діяльності в історично різних особливих їі формах, що дало б змогу продуктивно спрямовувати практичні зусилля всіх її суб'єктів на формування їхніх культурних потреб розвитком їхніх креативних (творчих) здібностей. (Див. постулати загального людинознавства).

Звідси є практичний висновок-вказівка: предметом діяльності всіх суб'єктів освітньої діяльності служить не тріада - знання, уміння й навики, а культурні потреби і творчі здібності учителів, учнів, батьків, управлінців і всіх тих, хто так чи інакще включається у простір освітньої ді- 
яльності. Зокрема - потреба у своїх знаннях, а не в заучених чужих, i не стільки здатність засвоювати напрацьовані іншими уміння й навики, скільки здатність творчо перетворювати умови їх набуття. [8]

Філософія ж освіти в кращому випадку - філософсько рефлексивна критика емпіризму в педагогічній теорії, але ніяк не іiі “частина”, що претендує на “загальний підхід” до багатоманіття освітніх практик, що намагаються реалізувати абстракти не менш різноманітних педагогічних концепцій. Але тоді ця критика - просто сократична, маєевтична функція філософії як такої.

Відповідно до розрізнення, зробленого Ф. Михайловим, учених, які розмірковують про освіту і відносяться до філософів освіти можна поділити на дві категорії: власне філософів освіти та філософів в освіті. Перші на тему педагогіки намагаються культивувати той чи інший різновид часткової філософської науки. Другі працюють над визначенням тієї фундаментальної предметної основи, на якій можна будувати справжню педагогічну (освітню) теорію, якої поки що немає.

$* * *$

Професор А. Гжегорчик відноситься до другої категорії - він є філософом в освіті. Вихідним пунктом всіх без винятку розмірковувань філософа на будь-яку тему, за яку б він не брався - вважав логіку. Відповідно, методологічною базою та підставою будь-яких «порядних» теоретичних побудов була філософія, яку він культивував у іiі науковій версії (philosophy as science) і яку ще називають науковою, аналітичною чи раціоналістичною. Як написав Станіслав Краєвський, „у рамках позалогічної проблематики Гжегорчик береться за проблеми з етики й філософської антропології, завжди з чітким методологічним самоусвідомленням, у рамках філософії, яку назвав „раціоналізмом, відкритим до цінностей”. На його переконання, незалежно від мотивації, з якою ми беремося розмірковувати, критерієм цінності цих розмірковувань є логіка. Те, чи умовивід є логічний, систематичний, самоусвідомлений” [32].

І у своїй прикладній частині ця філософія, а точніше - філософування Анджея Гжегорчика - якраз і надає оту «фундаментальну основу», про яку писав Ф. Михайлов.

Ба, більше, задовго до Ф. Михайлова А. Гжегорчик шукає цю основу там же де й російський вчений - в науках про людину, тільки називає цю сферу не екзотичним словом «людинознавство», а загальноприйнятим міжнародним терміном «антропологія». Але й це не все. Професор Гжегорчик опрацьовує саме отой «реально-ідеальний простір освітнього спілкування», на який Ф. Михайлов лише вказує, як на предмет педагогічної теорії. Йдучи значно далі, ніж його російський колега, А. Гже- 
горчик, розвивав концепцію так званої «Універсальної шкільної програми», спираючись на поняття „освітніх середовищ”, які він представив iз антропологічної точки зору, вирізняючи чотири етапи пізнавального розвитку індивіда, пов'язані з домінуванням однієї з перспектив, що почергово з'являються в житті молодої особи, а саме: 1) родинно-сусідський, пов'язаний із найближчим сімейним і сусідським оточенням, яке передає традиційні цінності, 2) національно-традиційно-релігійний, пов'язаний із впливом етнічного та релігійного оточення, в якому відбувається поширення традиційних цінностей, зокрема, у вигляді участі разом із сім'єю в етнічних і релігійних інституціях, а також релігійних елементів у шкільному житті, 3) інтелектуально-раціоналістично-науковий, пов'язаний із набуванням власних знань про дійсність, а також із прагненням самостійно приймати важливі рішення, в оперті на отримане знання, як також можливе відкидання традиційних цінностей (бунт проти норм, нав'язаних традиційним оточенням), 4) загально-життєвий, що універсалізує набутий досвід $[4,21]$. У цьому поділі названі середовища вказують на головні суб'єкти, які творять освітнє середовище індивіда в процесі його дозрівання.

Використовуючи експеримент, проведений в одній з автономних республік Російської Федерації프, у рамках цієї концепції, Професор Гжегорчик встановив також чотири розділи освітніх змістів і їхню градацію, згідно з переліченими вище етапами пізнавального розвитку індивіда. А саме: Культура (участь у культурі регіону та світу), Екологія (техніки гармонійного співіснування у природних, технічних і суспільних середовищах), Бізнес (господарська діяльність), а також Суспільні інціативи (участь у міжлюдській комунікації та пошук свого місця в суспільстві).

Непомічена професійними філософами концепція Універсальної шкільної програми тим не менш, є чи не єдиною науковою пропозицією надання методологічної основи для розв’язання добре відомої дидактам проблеми ,добору канону шкільного знання”, артикульованої в період декади реформ в Європейському Союзі ${ }^{2}$, до яких (реформ) Польща долучилася у 1990-х роках, а Україна щойно тепер робить другу спробу такого долучення. У знаменитій „блакитній книжечці” по це було сказано

${ }^{1}$ Експеримент з впровадження Універсальної шкільної програми, у рамках тодішньої польсько-російської співпраці, був проведений у середніх школах Автономної Республіки Бурятія під керівництвом Зої Морохоєвої та Станіслава Запасніка. Загальна схема теоретичної концепції цієї програми п.н. Universalistic Social-Education була представлена в серпні 1998 року на III Конгресі Універсалізму в Babson College (США). (O.H.)

${ }^{2}$ Zob. Dekada reform w ksztatceniu obowiąkowym w Unji Europejskiej (1984-1994) // W.: EURIDICE, 1999, 324 s. 
прямо: „Шораз важче приймати рішення щодо канону знання, який повинен бути переданий учневі в системі загальної освіти”[33].

На мою думку, це - вражаючий приклад відкриття чогось „очевидного-неймовірного”, а саме - постановки питання: „чому у шкільних підручниках знаходяться відомості, які там... власне й знаходяться?" Або: „що, власне кажучи, має бути вміщене у шкільні програми та підручники і чому?”. Питання, яких до цієї пори ніхто серйозно не ставив. Історично склалося так, що шкільне знання розвивалося диференційоване предметно, в міру розвитку окремих наукових і культурних галузей, які вважалися цінними, з точки зору їх передання наступним генераціям. Іншими словами, професійні математики вирішували, якими мають бути програми шкільної математики, фізики - фізики, історики - історії і т.д. А чиновники згори ,затверджували” шкільні програми. I якось це йшло. До тієї пори, поки не винайшли комп'ютери, інтернет і засоби комунікації, що перетворили Землю в глобалізоване інформаційне (а відтак - освітнє) середовище, в якому всіх шкільних змістів можна легко навчитися поза школою - взагалі не ходячи на уроки. Якщо ж взяти до уваги факт, що в межах школи, під час астрономічного року, пересічний учень проводить заледве $10 \%$ часу своєї активності, то проблема зацікавлення учня шкільним знанням і проблема ефективності обов'язкової шкільної освіти взагалі - стає проблемою глобальною, принаймні - у розвинених країнах. Ця проблема особливо актуалізується в контексті творення єдиного освітнього простору об’єднаної Европи - що є „червоною ниткою” Болонського процесу, учасниками якого є Україна та Польща.

Отож схема Універсальної шкільної програми в представленні Професора Гжегорчика визначає фундаментальні для педагогіки антропологічні критерії добору саме отого „канону шкільного знання”. Самі ці критерії ще слід уточнити та деталізувати вже в межах вікової психології та власне дидактики - загальної та предметної. 3 цього погляду Професор Гжегорчик перебуває на вершині актуальної теоретико-дидактичної думки.

Друга царина, в якій філософ Гжегорчик прислужується педагогіці теорія виховання. Тут, в оперті на етичну концепцію «загальнолюдської солідарності», він розвиває теорію діалогу як головного знаряддя (засобу, методу і т.д.) суспільного розвитку. У педагогіці поняття «діалог» вже давно визнане одним із основних умінь чи компетентностей, яке слід виховувати у молоді, а відтак - однією з головних цілей освіти. В англійській термінології іiі називають „діалогічним і діалектичним умінням”.

${ }^{1}$ Діалектичне вміння тут розуміється у первинному грецькому значенні діалектики: dia - два, lektos - мовець; dialektos - „два мовці”, тобто вміння провадити дискусію з партнером, або - вміння всебічно обміркувати проблему самостійно, коли співрозмовника немає. (O.H). 
Педагоги впровадили це поняття до категорії виховних цілей, виходячи з утилітарних чи практичних міркувань, а саме - 3 того, що величезне зростання урбанізації та збільшення концентрації людей на одиницю площі у містах, призвели до збільшення вимушених персональних міжлюдських контактів. Це створює таку ситуацію щоденного функціонування індивіда, в якій необхідною умовою безпечного та корисного його «виживання в натовпі» $\epsilon$ вміння проводити безліч випадкових і вимушених контактів з іншими людьми - тобто ота діалогічна компетентність.

Гжегорчик, натомість, виводить діалог з основної людської кондиції, тобто того, „що становить сутність людськості, а в зв'язку з цим - із здатності творити нові поняття, теорії, класифікації, того, що він називав „метазнаряддя розуму” [32]. І лише в такий спосіб з'ясовує значення діалогу не тільки у вимірі життя індивіда, але також у вимірі життя всіх спільнот: родинних, локальних, професійних, релігійних, національних (див. напр. [3, 5, 18, 27, 30]).

Отже, Професор Гжегорчик опрацьовував антропологічні основи освіти [23], спираючись на свої дослідження стосовно людської кондиції. У своєму листі до Анджея Вуйціцького він представив стислу концепцію проекту цих досліджень: „Філософування - це оперування словами. Цього люди вчаться вже кілька десятків тисяч років. І витворили способи виражання (у щоденних застосуваннях) певних властивостей дійсності, що мають доволі повсюдний характер і зараз трактуються як властивості, досліджувані філософією. У рамках цього натурального розвитку людських мов, були витворені способи виражання екзистенціальних зв'язків (чи загальних рис), таких як: ідентичність, змінність, часовість, можливість, множинність (зв'язки між множинами), необхідність, бажаність і інші. Таким чином, висновок з еволюціоністського погляду, є такий: філософський погляд на світ існує в людському мисленні від початку існування виду. А способи його вираження були систематизовані великою мірою через граматичні конструкції. В такий спосіб, через мовну практику, філософія входить до кожної царини людської думки. Наукова філософія повинна це тільки, передусім, відповідно впорядкувати. 3 цієї повсюдної мовної практики вже можна видобути опис людської кондиції, що є основним завданням наукової філософії. У попередніх тисячоліттях не було теорії людської кондиції, що задовольняла б таким методологічним умовам, які тепер ми ставимо собі, коли хочемо щось порядно описати" [28].

Якщо коротко підсумувати сказане, то Професор Анджей Гжегорчик опрацював антропологічні основи педагогіки у вигляді загального опису людської кондиції, з яких вивів і обгрунтував основні критерії добору канону шкільного знання у вигляді схеми універсальної освітньої про- 
грами. Сьогодні це становить одну із найактуальніших проблем сучасної дидактичної теорії. Тому, з точки зору професора Ф. Михайлова, Професор Анджей Гжегорчик фактично є одним із засновників метадидактики, щонайменше - одним із ії провісників. Що є чудовим прикладом ролі філософа в освіті.

Якщо ж хтось не погоджується з Феліксом Михайловим і вважає, що філософія освіта - це законна наукова дисципліна, тоді Професор Гжегорчик безсумнівно належить до грона засновників філософії сучасної освіти.

\section{Література:}

1. Гжегорчик А. Декалог розуму // Педагогічна думка, №4. - Львів: ЛОІППО. - 2007, CC. 41-43.

2. Гжегорчик А. Життя як виклик. Вступ до раціоналістичної філософії. - Warszawa: Scholar - Львів: ВНТЛ. - 2003. - 288 с.

3. Гжегорчик А. Інтелектуальні виклики міжрелігійного діалогу // Педагогічна думка, №4’2008. - Львів: ЛОІППО. - 2008, СС. 57-60.

4. Гжегорчик А. Освіта майбутнього // Українські варіанти, №3-4. - Львів. - 1999, CC. 43-47.

5. Гжегорчик А. Польсько-українські стосунки та філософія // Українські варіанти, №2(4). - Львів. - 1998. СС. 49-56.

6. Grzegorczyk A. Dekalog po świecku odczytany // Biblioteka „Więzi”. - 1962.

7. Гжегорчик А. Популярная логика. - М. 1965. - 130 с.

8. Михайлов Ф. Философия образования - её реальность и перспективы. - М.: Академия. - 2001. - $256 \mathrm{c.}$

9. Grzegorczyk A. Logika Popularna. - W.: PWN, 1955¹ $1958^{2}, 1961^{3}$. - $130 \mathrm{~s}$.

10. Grzegorczyk A. Zarys arytmetyki teoretycznej - W.: PWN. $-1971^{1}, 1983^{2}$. $-314 \mathrm{~s}$.

11. Grzegorczyk A. Zarys logiki matematycznej. - W.: PWN, 1961 ${ }^{1}, 1973^{2}, 1975^{3}, 1981^{4}$, $1984^{5} .-288 \mathrm{~s}$.

12. Grzegorczyk A. Moralitety. - W.: PAX, 1986, $176 \mathrm{s.}$

13. Grzegorczyk A. Etyka w dóswiadczeniu wewnętrznym. - W.: PAX. - 1989, 473 s.

14. Grzegorczyk A. Mat a propedeutyka filozofii naukowej. - W.: PAX, 1989, $116 \mathrm{~s}$.

15. Grzegorczyk A. Filozofia cztowieka a pedagogika. // Humanizm, Prakseologia. Wrocław: OSSOLINEUM, 1989, SS. 199-208:

16. Grzegorczyk A. Tolerancja - pokonanie wtasnej pychy. // Problemy opiekuńczo-wychowawcze. №7. - 1995 (wktadka: Przygotowanie do życia), SS. 2-3.

17. Grzegorczyk A. Dekalog rozumu // Nauka i Język (red. Jerzy Pelc) vol. 32. Wydział Filozofii i Socjologii UW. - W. - 1995, SS. 91-86.

18. Grzegorczyk A. Stosunki polsko-ukraińskie a filozofia. // Przęgląd Filozoficzny, V.4 (20). - 1996. SS. 135-146.

19. Grzegorczyk A. Non-violence wychowanie do negocjacji, demokracji i wspótistnienia. // Edukacja wobec wyzwań XXI wieku. Komitet Prognoz Polska 2000. - W.: PAN. - 1996. SS. 57-92. 
20. Grzegorczyk A. Życie jako wyzwanie. Wprowadzenie w filozofię racjonalistyczną. - W.: IfiS PAN. $-1993^{1},-1997^{2} .-288 \mathrm{~s}$.

21. A. Grzegorczyk, Z. Morokhojewa, S. Zapasnik. Universalistic Social Edukation // Dia$\log$ and Universalism, vol. VIII. №5-6. - 1998. SS. 159-163.

22. Grzegorczyk A. Czasy i wyzwania // Pedagogika czasu przemian. - W.: ZM WSPS. 1999. SS. 9-21.

23. Grzegorczyk A. Antropologiczne podstawy edukacji globalnej // Forum óswiatowe. №1-2 (20-21). - Toruń. - 1999. SS. 5-13.

24. Grzegorczyk A. Czasy $i$ wyzwania // Wspólnotowość i postawa uniwersalistyczna, №3/2002-2003. - W.: APS. - 2003. SS. 5-20.

25. Grzegorczyk A. Psychiczna osobliwóśc cztowieka.- W.: Scholar. - 2003. - 174 s.

26. Grzegorczyk A. Użytkowanie „rozumu” a stan aktualny ludzkósci // Bogdan Suchodolski, w stulecie urodzin - trwałość inspiracji. - W.: Komitet Prognoz PAN. - 2004. SS. 257-274.

27. Grzegorczyk A. Wyzwania intelektualne dialogu międzyreligijnego // B. Weigl, O. Hirnyy (red.). Wykłady Uniowskie 2008.- L.: Prostir-M.-2008.- 318 s. SS. 61-74.

28. Grzegorczyk A. List do Andrzeja Ryszarda Wójcickiego z 29 maja 2008 r. // http://www. ifispan.waw.pl/studialogica/s-p-f/forum-files/Grzegorczyk-Wojcicki.pdf

29. Grzegorczyk A. Logika Popularna. Przystepny zarys logiki zdan̨. - W.: PWN. - 2010. $104 \mathrm{~s}$.

30. Grzegorczyk A. Dialog międzyreligijny wierzacych w jedynego Boga // B. Weigl, O. Hirnyy (red.) Wykłady uniowskie 2010-2012. - Lwów: Prostir-M. - 2013. - 304 s., SS. 29-31.

31. Hirnyy O. Nauczanie propedeutyki filozoficznej wedtug ksiątki A. Grzegorczyka „Życie jako wyzwanie. Wprowadzenie w filozofie racjonalistyczna” // B. Burlikowski, W.Słomski (red.) Filozofia w szkole III. - Kielce: Ákademia Świętokrzyska - W-: Polskie Towarzystwo Filozoficzne. - 2002. - 628 s. SS. 212-224.

32. Krajewski S. Andrzej Grzegorczyk - logika i religia, samotność $i$ solidarnósć // Roczniki Polskiego Towarzystwa Matematycznego. Seria II: Wiadomości matematyczne XLIV (2008), SS. 53-59.

33. Reforma Systemu Edukacji. Szkolnictwo Ponadgimnazjalne (materiały do dyskusji). - W.: MEN. - 2000. - $135 \mathrm{~s}$.

34. Schnaedelbach H., Martens I. Filozofia. Podstawowe pytania. - W.: Wiedza Powszechna. $-1995 .-768 \mathrm{~s}$.

\section{Олег Гирный. Анджей Гжегорчик как философ образования}

В статье представлен научный портрет выдающегося польского учёного, последнего представителя знаменитой Львовско-варшавской логико-философской школы, большого друга Украины, профессора Анджея Гжегорчика, вторая годовщина смерти которого прошла в этом году. Кроме своей главной пассии - математической логики, в которой ему принадлежат признанные во всём мире результаты, Анджей Гжегорчик занимался этикой и философией, в частности тем её видом, который сам называл «рационализмом, открытым на ценности». 
Кратко описаны также его наработки в той сфере, которую часто называют «философией образования», хотя во многих случаях следует говорить скорее о «философии в образовании». Эта область незаслуженно считается второстепенной в его творчестве, хотя, на самом деле, имеет первостепенное значение для развития теоретических оснований педагогики. Особого внимания заслуживает, в частности, его научная программа антропологического описания так называемой «человеческой кондиции», а также разработаная им, на основании этого описания, так называемая «Универсальная учебная (школьная) программа».

Ключевые слова: логика, рационализм, ценности, философия образования, теоретические основания педагогики, человеческая кондиция, антропологическое описание, универсальная учебная (икольная) программа.

\section{Oleg Hirnyy. Andrzej Grzegorczyk as a Philosopher of Education}

The paper presents scientific portrait of the famous Polish scientist, the last representative of the famous Lviv-Warsaw logical-philosophical school, a great friend of Ukraine, Professor Andrzej Grzegorczyk, who died two years ago. In addition to his main passion - mathematical logic, in which he has the world class results. Andrzej Grzegorczyk studied ethics and philosophy, in particular in such its sphere, which he called "rationalism, opened to values".

It is briefly described his studies in that area, which is often called the "philosophy of education", although in many cases it should say rather the "philosophy in education". This research sphere is undeservingly considered as a peripheral one in his work. In fact it is of prime importance for the development of the theoretical bases of pedagogy. In particular, his scientific program of anthropological description (so-called "human condition") and based on this description the program developed by him (so-called "Universal School Program") deserve the special attention.

Keywords: logic, rationality, values, philosophy of education, the theoretical bases of pedagogy, human condition, anthropological description, Universal School Program.

Гірний Олег Ігорович - кандидат технічних наук, доцент кафедри природничо-математичної освіти Львівського обласного інституту післядипломної педагогічної освіти.

E-mail: ohirnyy@ukr.net

Hirnyy Oleh I. - PhD, assistant professor, Lviv Regional Institute of Postgraduate Pedagogical Education, Department of Natural Sciences and Mathematics Education; Position - docent. 